\title{
Merozoite surface protein 2 allelic variation influences the specific antibody response during acute malaria in individuals from a Brazilian endemic area
}

\author{
Selma Sallenave-Sales, Clarissa Perez Faria, Mariano Gustavo Zalis*, \\ Cláudio Tadeu Daniel-Ribeiro, Maria de Fátima Ferreira-da-Cruz ${ }^{+}$
}

\begin{abstract}
Departamento de Imunologia, WHO Collaborating Center for Research and Training in the Immunology of Parasitic Diseases, Instituto Oswaldo Cruz -Fiocruz, Av. Brasil 4365, 21040-900 Rio de Janeiro, RJ, Brasil *Departamento de Medicina Preventiva, Hospital Universitário Clementino Fraga, UFRJ, Rio de Janeiro, RJ, Brasil
\end{abstract}

The antibody response to Plasmodium falciparum parasites of naturally infected population is critical to elucidate the role of polymorphic alleles in malaria. Thus, we evaluated the impact of antigenic diversity of repetitive and family dimorphic domains of the merozoite surface protein 2 (MSP-2) on immune response of 96 individuals living in Peixoto de Azevedo (MT-Brazil), by ELISA using recombinant MSP-2 proteins. The majority of these individuals were carrying FC27-type infections. IgG antibody responses were predominantly directed to FC27 parasites and were correlated to the extension of polymorphism presented by each MSP-2 region. This finding demonstrated the impact of the genetic polymorphism on antibody response and therefore, its importance on malaria vaccine efficacy.

Key words: Plasmodium falciparum - merozoite surface protein-2 - antibody response - antigenic polymorphism - malaria

It has been suggested that the genetic variability of the parasite could allow its evasion from immune responses induced by previous infections with parasites expressing variant antigenic forms. Genetic modifications in antigenic epitopes could induce conformational changes in the polypeptide structure resulting in the lack of putative reactive sites at the protein surface, as well as in different presentation of these sites to the immune system (Ranford-Cartwright et al. 1996, Tonhosolo et al. 2001, Kanunfre et al. 2003). Consequently, studies on the relationship of genetic diversity of B epitopes in parasite surface antigens and its impact on the recognition of antibodies generated during natural infections should be carried out for designing immunization strategies.

The genetic polymorphism of the merozoite surface protein 2 (MSP-2) of Plasmodium falciparum has been studied due to its applicability as a target for a malaria vaccine development and its putative association with antibody-mediated protection (Taylor et al. 1995, Genton et al. 2003, Scopel et al. 2006). The MSP-2 allelic families - known as ICI/3D7 and FC27 - corresponding, respectively to two antigenically distinct serogroups: A and $\mathrm{B}$, which are frequently and strongly recognized by antibodies from malaria-exposed individuals (Fenton et al. 1990, Ekala et al. 2002). These antibodies are preferably directed against the central variable region of the molecule, which is composed by tandem repeats blocks (R1 and R2) flanked by family dimorphic blocks. The

Financial support: IOC-Fiocruz, $\mathrm{CNPq}$

+Corresponding author: mffcruz@ioc.fiocruz.br

Received 2 March 2007

Accepted 2 May 2007
FC27 family has shown different numbers of the relatively conserved R1 (32-mer) and R2 (12-mer) repetitive regions. The R1 repeats of 3D7 family, characterized by shorter sequence repeats of 3 to 10 residues, can vary considerably although they are usually glycine, serine and alanine rich, while the $\mathrm{R} 2$ region is a well conserved repeat rich in the amino acid threonine. It has been suggested that naturally immunodominant epitopes are encoded within the repetitive sequences of the molecule (Smythe et al.1990).

Our group previously identified (Sallenave-Sales et al. 2003) polymorphic alleles from both MSP-2 families in P. falciparum isolates collected during a drug surveillance carried out between May 1995 and January 1996 in Peixoto de Azevedo village (state of Mato Grosso, Brazil). The village population consisted mainly in migrant individuals exposed during all the year to the risk of malaria infection. At time of blood collection, the village had the highest malaria transmission rates in Brazil with an annual parasitic incidence (positive slides/ 1000 inhabitants) of 284.8 and 263.1 in 1995 and 1996, respectively. After signed consent, venous blood samples were obtained, before treatment, from 96 adults between 20 and 60 years of age with uncomplicated malaria and MSP-2 alleles were typed by SSCP-PCR and sequencing analysis. Here, we intend to analize the impact of such antigenic polymorphism on patient antibody responses. For this purpose, we tested plasma from these 96 patients against six recombinant proteins representing the R1 units repeats and family dimorphic regions of MSP-2 families, by ELISA. Three MSP-2 recombinant proteins were tested to each one of serogroup (A and B): A1, A2, A3 (ICI/3D7) and B1, B2, and B3 (FC27) (Figure). A1 and B1 represent full-length proteins without the $21 \mathrm{aa}$ and $17 \mathrm{aa}$ from $\mathrm{N}$ and $\mathrm{C}$ terminus, respectively; $\mathrm{A} 2$ and $\mathrm{B} 2$ represent the $\mathrm{R} 1$ repeat region and $\mathrm{A} 3$ 
I

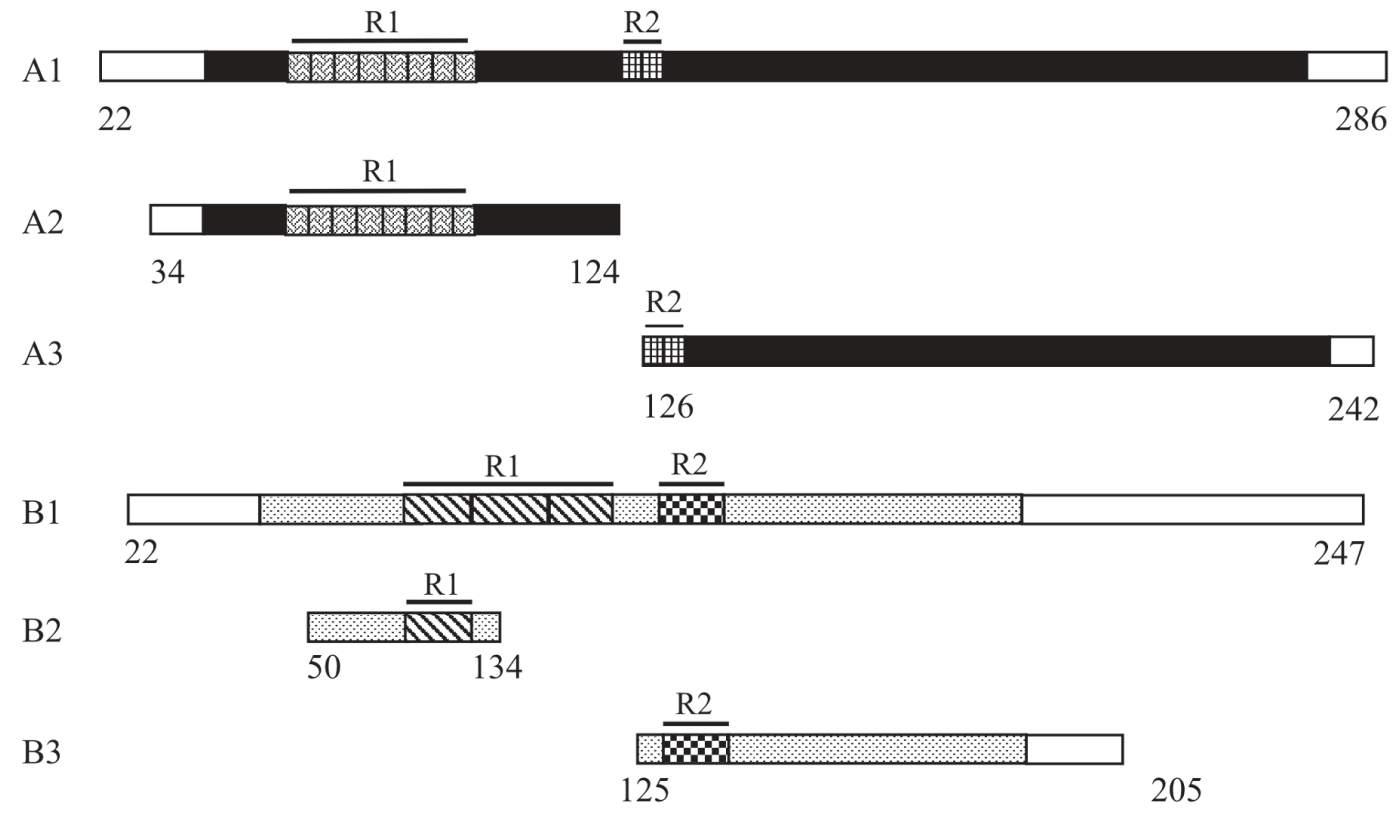

II

Allele Ia

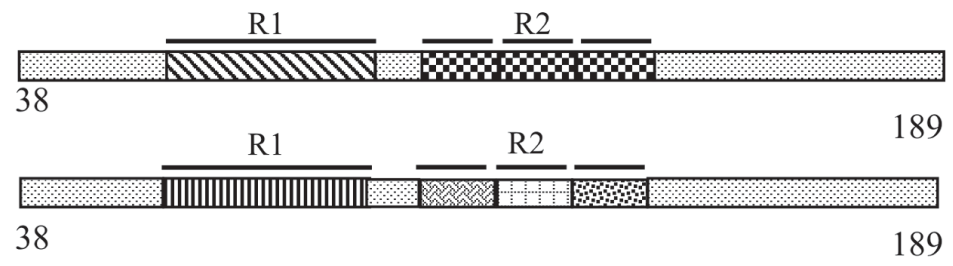

Allele II

$\mathrm{R} 1$

$\mathrm{R} 2$

$\begin{array}{ll}38 & 177\end{array}$

Allele III

$\mathrm{R} 1$

\begin{tabular}{lll}
\hline tot & . \\
38 & 217
\end{tabular}

III

Allele IVa

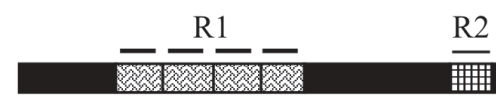

I - Schematic representation of the MSP-2 recombinant proteins (Taylor et al. 1995): A1 (T9/96) and B1 (Dd2) represent 3D7-type and FC27-type fulllength proteins without the 17aa and 21 aa from $\mathrm{N}$ and $\mathrm{C}$ terminus, respectively; A2 (T9/96) and A3 (R033) represent, respectively, R1 repeat region and dimorphic family + R2 regions in the C-terminal half of 3D7-type and B2 (K1) and B3 (T9/105) represent these same regions in FC27-type. II - Schematic representation of the predicted FC27 MSP-2 allelic sequences: the dotted blocks represent dimorphic family regions (E1-3) and the two blocks of tandem repeats (R1 and R2) are indicated. III - Schematic representation of the predicted 3D7 MSP-2 allelic sequences: the black blocks represent dimorphic family regions (E1-3) and the two blocks of tandem repeats (R1 and R2) are indicated. All predicted schemes were adapted from SallenaveSales et al. (2003). The numbers represent amino acid positions corresponding to published sequences of FC27 and 3D7 strains (Smythe et al. 1988, 1990). 
and B3 represent dimorphic family regions. These proteins were kindly provided by Dr Jana McBride group and the ELISA were performed as already described (Taylor et al. 1995).

The frequency of individuals positive to at least one MSP-2 protein was $81 \%$ (data not shown). The IgG antibody prevalence to each of the six recombinant MSP-2 proteins is shown in the Table. As expected, we observed that recombinant proteins of serogroup B (FC27-types) were better recognized than serogroup A (3D7-types), since FC27 alleles were the predominant type detected on $P$. falciparum parasites infecting these individuals. Similar results using another set of MSP-2 recombinant proteins were reported by Kanunfre et al. (2003) studying malaria patients from the same village - Peixoto de Azevedo - contrasting to data reported by Taylor et al. (1995) that even using the same recombinant proteins, observed a predominance of 3D7 antibodies (serogroup A) in a comparable analysis conducted in Gambia.

We also detected a significant number of individuals responders to B1 (central variable region) and B2 (R1 region) recombinant proteins. Near $60 \%$ (44 out of 76) of the individuals that carried parasites type FC27 had antibodies to the first repetitive region of molecule (B2) that is relatively conserved even in geographically distinct plasmodial isolates. Interestingly, the two single individuals infected with allele III had antibodies to B2 recombinant protein, suggesting that the presence of three units at $\mathrm{R} 1$ region of this allelic type should contribute to the antigenicity of this recombinant protein (Figure). In contrast, the total deletion of $\mathrm{R} 2$ region in allele III sequence could be responsible for the lack of reactivity sites at the surface of the molecule (Figure). In fact, we observed that individuals carrying parasites with allele III do not respond to B3 recombinant protein which represents the dimorphic family region of FC27 type including $\mathrm{R} 2$ region. The non response or a low antibody response to MSP-2 recombinant protein containing one or no 12-mer repeats (units) in $\mathrm{R} 2$ region may indicate that such variation in the number of tandem repeats could allow the parasite to avoid high avidity antibody binding and it was already reported (RanfordCartwright et al. 1996). Curiously, we did not detected antibody response in individuals infected with parasites carrying alleles Ia or II, that shared two identical repeats in $\mathrm{R} 2$ region. In addition, only $8 \%$ of individuals infected with allele Ib type parasites recognized B3 recombinant protein, possibly due to sequence diversity between Brazilian MSP-2 genotypes and the reference strain (T9/ $105)$ that originate the recombinant protein (Figure).

Contrasting to FC27-type recombinant proteins, only $20 \%$ (19 out of 96 ) of studied individuals presented antibodies to 3D7-type ones (serogroup A) (Table). The frequency of antibody response to A1 (central variable region) and $\mathrm{A} 3$ (dimorphic region including $\mathrm{R} 2$ repeats) were the same but only one patient had antibodies to the first repetitive region of molecule (A2). As observed in the case of B3 recombinant protein, low antibody recognition to A2 was detected in individuals carrying allele IVa, or carrying this allele in association to the allele FC27 Ib (Table). Once again this result could be related to sequence polymorphism of Brazilian MSP-2 genotypes in relation to the reference strain (T9/96) that originate the recombinant protein since amino acid sequence of the $\mathrm{R} 1$ repeats from different isolates could vary extensively (Figure) (Ferreira \& Hartl 2007).

In summary, the antibody response to B1 and B2 (FC27-type) and A1 and A3 (3D7-type) recombinant proteins may be associated to the extension of polymorphism presented by each MSP-2 region, since we found an inverse relationship between such polymorphism and the frequency of immune response. In respect to B3 recombinant protein, the variable number and sequence diversity of $\mathrm{R} 2$ repetitive units would be responsible for the low antibody reaction against this recombinant protein. Similarly, the high variability in length, sequence and copy number of $\mathrm{R} 1$ region, could explain the poor antibody reaction with the $\mathrm{D} 2$ recombinant protein.

TABLE

IgG antibody response to MSP-2 recombinant proteins of 96 malaria patients from Peixoto de Azevedo (MT- Brazil), according to allelic type

\begin{tabular}{|c|c|c|c|c|c|c|c|}
\hline \multirow{3}{*}{$\begin{array}{l}\text { MSP-2 } \\
\text { family }\end{array}$} & \multirow{3}{*}{$\begin{array}{c}\text { Allele } \\
\text { identified } \\
\text { (n) }\end{array}$} & \multicolumn{3}{|c|}{$\begin{array}{c}\text { 3D7-type } \\
\text { recombinant proteins }\end{array}$} & \multicolumn{3}{|c|}{$\begin{array}{c}\text { FC27-type } \\
\text { recombinant proteins }\end{array}$} \\
\hline & & A1 & A2 & A3 & B1 & B2 & B3 \\
\hline & & \multicolumn{6}{|c|}{$\begin{array}{c}\text { IgG antibody response } \\
\text { R }(\%)\end{array}$} \\
\hline $\mathrm{FC} 27$ & Ia (13) & $0(0)$ & $0(0)$ & $1(8)$ & $9(69)$ & $10(77)$ & $0(0)$ \\
\hline $\mathrm{FC} 27$ & $\mathrm{Ib}(50)$ & $6(12)$ & $0(0)$ & $6(12)$ & $39(78)$ & $27(54)$ & $4(8)$ \\
\hline $\mathrm{FC} 27$ & II (5) & $3(60)$ & $0(0)$ & $3(60)$ & $3(60)$ & $3(60)$ & $0(0)$ \\
\hline $\mathrm{FC} 27$ & III (2) & $0(0)$ & $0(0)$ & $0(0)$ & $2(100)$ & $2(100)$ & $0(0)$ \\
\hline $3 \mathrm{D} 7$ & IVa (20) & $8(40)$ & $1(5)$ & $6(30)$ & $13(65)$ & $5(25)$ & $1(5)$ \\
\hline FC27/3D7 & $\mathrm{Ib} / \mathrm{IVa}(6)^{a}$ & $2(34)$ & $0(0)$ & $2(34)$ & $4(66)$ & $2(34)$ & $0(0)$ \\
\hline
\end{tabular}

The plasmas were diluted 1:100 and/or 1:500 and tested in duplicate with six MSP-2 fusion proteins and also with the fusion protein GST, as already described by Taylor et al. (1995). Negative control plasma samples were obtained from 20 adults who had not been exposed to malaria. R: number of responders; $\mathrm{n}$ : number of alleles; $a$ : mixed infection: presence of two allelic types in the same $P$. falciparum isolate. 
Finally, we conclude that the genetic polymorphism of MSP-2 protein in P. falciparum parasites could influence the development of specific antibody immune response in Brazilian populations. Analysis of the antibody response using recombinant proteins representing MSP-2 allelic types found in Peixoto de Azevedo village will done to better understanding the immune response to MSP-2 alleles.

\section{ACKNOWLEDGEMENTS}

To Dr Jana McBride for providing MSP-2 recombinant proteins.

\section{REFERENCES}

Ekala MT, Jouin H, Lekoulou F, Mercereau-Puijalon O, Ntoumi F 2002. Allelic family-specific humoral responses to merozoite surface protein 2 (MSP2) in Gabonese residents with Plasmodium falciparum infections. Clin Exp Immunol 129: 326-331.

Fenton B, Walliker D 1992. Genetic analysis of malaria parasites. Subcell Biochem 18: 307-331.

Ferreira MU, Hartl DL 2007. Plasmodium falciparum: worldwide sequence diversity and evolution of the malaria vaccine candidate merozoite surface protein-2 (MSP-2). Exp Parasitol 115: 32-40.

Genton B, Al-Yaman F, Betuela I, Anders RF, Saul A, Baea K, Mellombo M, Taraika J, Brown GV, Pye D, Irving DO, Felger I, Beck HP, Smith TA, Alpers MP 2003. Safety and immunogenicity of a three-component blood-stage malaria vaccine (MSP1, MSP2, RESA) against Plasmodium falciparum in Papua New Guinean children. Vaccine 22: 30-41.

Kanunfre KA, Leoratti FM, Hoffmann EH, Durlacher RR, Ferreira AW, Moraes-Avila SL, Ferreira MU 2003. Differential recognition of Plasmodium falciparum merozoite surface protein 2 variants by antibodies from malaria patients in Brazil. Clin Diagn Lab Immunol 10: 973-976.
Ranford-Cartwright LC, Taylor RR, Asgari-Jirhandeh N, Smith DB, Roberts PE, Robinson VJ, Babiker HA, Riley EM, Walliker D, McBride JS 1996. Differential antibody recognition of FC27-like Plasmodium falciparum merozoite surface protein MSP-2 antigens which lack 12 amino acid. Par Immunol 18: 411-420.

Sallenave-Sales S, Ferreira-da-Cruz MF, Faria CP, Cerruti CJ, Daniel-Ribeiro CT, Zalis MG 2003. Plasmodium falciparum: limited genetic diversity of MSP-2 in isolates circulating in Brazilian endemic areas. Exp Parasitol 103: 127-135.

Scopel KKG, Fontes CJF, Ferreira MU, Braga EM 2006. Factors associated with immunoglobulin $\mathrm{G}$ subclass polarization in naturally acquired antibodies to Plasmodium falciparum merozoite surface proteins: a cross-sectional survey in Brazilian Amazonia. Clin Vaccine Immunol 13: 810-813.

Smythe JA, Coppel RL, Brown GV, Ramasamy R, Kemp DJ, Anders RF 1988. Identification of two integral membrane proteins of Plasmodium falciparum. Proc Natl Acad Sci USA 85: 5195-5199.

Smythe JA, Coppel RL, Brown GV, Ramasamy R, Kemp DJ, Anders RF 1990. Structural diversity in the 45-kilodalton merozoite surface antigen of Plasmodium falciparum. Mol Bioch Parasitol 39: 227-234.

Taylor RR, Smith DB, Robinson VJ, McBride JS, Riley EM 1995. Human antibody response to Plasmodium falciparum merozoite surface protein 2 is serogroup specific and predominantly of the immunoglobulin G3 subclasses. Infect Immun 63: 4382-4388.

Tonhosolo R, Wunderlich G, Ferreira MU 2001. Differential antibody recognition of four allelic variants of the merozoite surface protein-2 (MSP-2) of Plasmodium falciparum. $J$ Eukaryot Microbiol 48: 556-564. 